\title{
Two new records of Pycnogonids on the Uruguayan coast
}

\author{
Carranza, A. ${ }^{\mathrm{a} *}$, Borthagaray, $A .^{\mathrm{a}}{ }^{\mathrm{a}}$ and Genzano, GN. ${ }^{\mathrm{b}}$ \\ anvestigación \& Desarrollo, Facultad de Ciencias, Universidad de la República, \\ Iguá 4225, CP 11400, Montevideo, Uruguay \\ bepartamento de Ciencias Marinas, Facultad de Ciencias Exactas y Naturales, Universidad Nacional de Mar del Plata, \\ Funes 3250 (7600) Mar del Plata, Argentina \\ *e-mail: alvardoc@fcien.edu.uy \\ Received September 8, 2005 - Accepted May 10, 2005 - Distributed May 31, 2007
}

(With 2 figures)

\begin{abstract}
The Pycnogonida from Uruguayan waters are scarcely known, and their reports are markedly discontinuous. In this paper, several individuals of two previously unrecorded Pycnogonids at the shallow rocky subtidal and lower intertidal fringes of Cerro Verde (Rocha, Uruguay) are reported. The specimens were assigned to Pycnogonum pamphorum Marcus, 1940 and Anoplodactylus petiolatus (Kroyer, 1844). This is the first record of these species on the Uruguayan coast and the southernmost record of P. pamphorum, previously recorded only in Santos, Brazil (type locality).
\end{abstract}

Keywords: Pycnogonida, Pycnogonum, Anoplodactylus, Uruguay.

\section{Dois novos registros de Pycnogonida para a costa Uruguaia}

\begin{abstract}
Resumo
Pouco se conhece da fauna dos Pycnogonida de águas Uruguaias, e seus registros são marcadamente descontínuos. Neste trabalho, são reportados vários indivíduos de dois picnogonídeos não registrados previamente, nas faixas rochosas submareal rasa e bordas intermareais baixas de Cerro Verde (Rocha, Uruguai). Os espécimes foram atribuídos às espécies Pycnogonum pamphorum Marcus, 1940 e Anoplodactylus petiolatus (Kroyer, 1844). Este é o primeiro registro dessas duas espécies para a costa Uruguaia e constitui o registro mais austral para P. Pamphorum, conhecido previamente somente em Santos, Brasil (localidade tipo).
\end{abstract}

Palavras-chave: Pycnogonida, Pycnogonum, Anoplodactylus, Uruguai.

\section{Introduction}

Pycnogonids or sea spiders are quite common in many different marine habitats from the intertidal zone to the abyssal depths. However, they are seldom seen due to their small size and cryptic coloration (Bain, 1991).

On the Uruguayan coast, the Pycnogonids are largely unknown, with the available literature referring only to the larger and more conspicuous species, such as the members of the genus Colossendeis. C. geofroyi MañeGarzón, 1944 was originally described from Uruguayan specimens and received further attention by Laramendy (1974), who analyzed material from the R/V "Walther Herwig" cruise in the Uruguayan continental shelf. Stock (1966) reported not only this species but also Tanystylum isthmiacum difficile Stock, 1955, Nymphon sp. and Pycnogonum elephas (Stock, 1966) for the South American Atlantic coast based on material collected by the R/V "Calypso". Additionally, Juanicó and Rodríguez-Moyano (1976) reported the presence of uni- dentified Pycnogonids associated with banks of Mytilus edulis platensis.

However, intertidal Pycnogonids have never been reported on the Uruguayan coast. In this paper, as part of a project dealing with benthic invertebrates biodiversity, two species found in the rocky intertidal of Cerro Verde (Rocha, Uruguay) are reported.

\section{Material and Methods}

\subsection{Study area}

Cerro Verde $\left(33^{\circ} 57^{\prime} \mathrm{S}\right.$ and $\left.53^{\circ} 30^{\prime} \mathrm{W}\right)$ is a rocky cape on the east coast of Uruguay (Figure 1). On each side of the cape there are sandy beach arcs that extend for 2-3 km. The coast experiences a semidiurnal tide (range $<0.5 \mathrm{~m}$ ) and the water level is mainly influenced by wind conditions (direction and speed). Winds blow south-west during the winter and north-east during the summer. The 


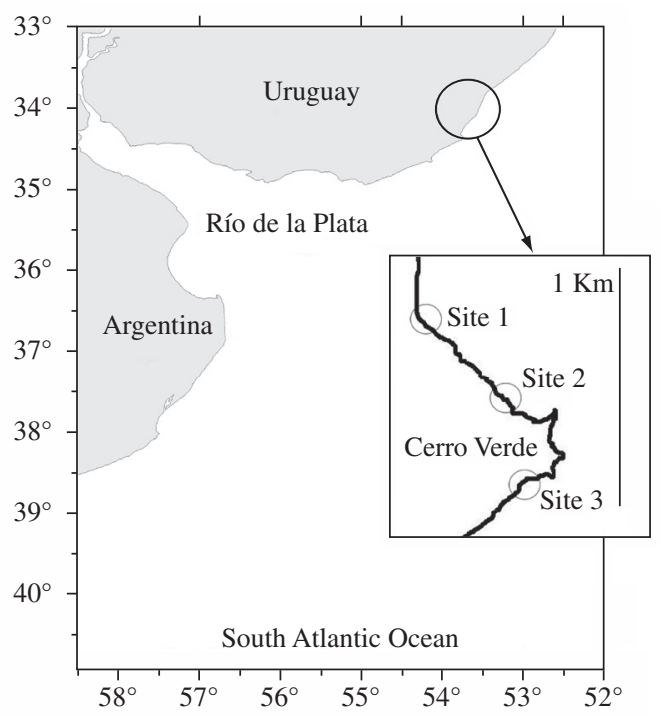

Figure 1. Map of South American Atlantic coast, showing the study region along the coast of Uruguay.

rocky platforms have a smooth slope, with a width ranging from 15 to $23 \mathrm{~m}$, and are exposed to different degrees of wave action according to its orientation. In these, three zones, following the classical zonation schemes, can be identified: a high intertidal zone dominated by a cyanobacterial film, a middle intertidal zone dominated by barnacles and a low intertidal and shallow subtidal zone characterized by a dense covering of mussels and/ or macroalgae.

\subsection{Sampling design}

Sampling was carried out on intertidal and shallow subtidal (i.e. depth $<1.5 \mathrm{~m}$ ) rocky platforms of the Cerro Verde area during February 2005. Three sampling sites $500 \mathrm{~m}$ apart were chosen along the coast: 1) exposed; orientated S-SW; 2) intermediate; and 3) protected, orientated N-NE. Within each site, we randomly selected points at each dominance zone (mid intertidal, low intertidal and shallow subtidal), separated by 2 to $10 \mathrm{~m}$. In each point, we placed one square of $20 \times 20 \mathrm{~cm}\left(0.04 \mathrm{~m}^{2}\right)$ and collected all macrofauna and algae present. Organisms were fixed and, in the laboratory, identified and counted. Frequency of occurrence was calculated as number of occurrences/ total samples for the dominance zone. Specimens were deposited in the collections of LABIC (Departamento de Ciencias Marinas, FCEyN - UNMdP).

\section{Results}

Within the macrofauna and associated with mussels, various individuals of two unrecorded Pycnogonids were collected (Figure 2a, 2b). The specimens were assigned to Pycnogonum pamphorum Marcus, 1940 (Pycnogonidae) and Anoplodactylus petiolatus (Kroyer, 1844) (Phoxichilidiidae). The 6 specimens of P. pamphorum (1 male and 5 females) were found in 3 samples

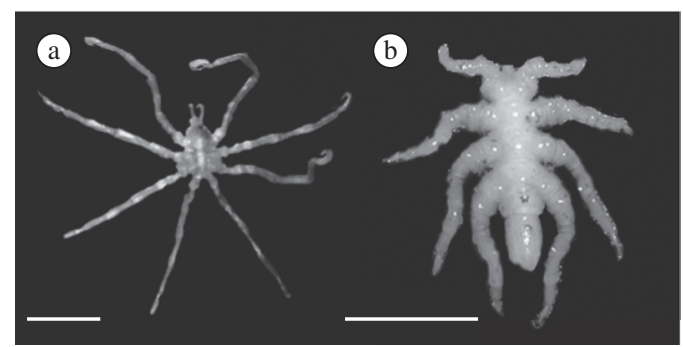

Figure 2. Specimens of a) Anoplodactylus petiolatus; and b) Pycnogonum pamphorum collected at the study site. Scale bar $=1 \mathrm{~mm}$

(frequency $=36.4 \%$ ) placed at the lower intertidal fringe at the protected and intermediate sites (Sites 1 and 2), whereas 12 specimens of $A$. petiolatus ( 8 males and 4 females) were collected from 3 samples (100\%) from the exposed shallow subtidal site and one sample (18.2\%) in the intermediate lower intertidal site. Associated benthic fauna includes the bivalves $B$. rodriguezii, Perna perna and Mytilus edulis platensis, various species of unidentified Anthozoa, syliid polychaetes, limpets and algae.

\section{Discussion}

This is the first record of both species for Uruguayan waters. $P$. pamphourm was previously mentioned only for the type localities (Bahia de Santos and Itanhaém, $53 \mathrm{~km}$ south of Santos, $23^{\circ} 56^{\prime} \mathrm{S}$ and $45^{\circ} 20^{\prime} \mathrm{W}$ ), associated to mussel beds (Marcus, 1940). Species belonging to the genus Pycnogonum are specialized feeders, most often recorded in association with anemones on which they feed (Staples, 2002).

In contrast, $A$. petiolatus is widely distributed in all oceans and mentioned for the southern Atlantic, from Brazil to Argentina. This species was recently found associated with Ectopleura (= Tubularia) crocea and Sarsia eximia in the Mar del Plata intertidal site in Argentina (Genzano, 2002), and its enclosed larvae are endo parasites on hydranths of different hydroid species (Staples and Watson, 1987; Genzano, op cit.).

Although the biodiversity of the Uruguayan rocky intertidal and shallow sub-tidal habitats is comparatively well known, taxonomic and faunal knowledge is limited and scattered for most groups of macrobenthos (Calliari et al, 2003). Molluscs and decapods are the best described taxonomic groups, while others like Pycnogonids, amphipods, isopods and polychaetes remain poorly known. At least two additional species of small $(<1 \mathrm{~cm})$ Pycnogonids have been found at the shallow rocky subtidal in the Atlantic coast of Uruguay and remain unreported, whereas another unidentified larger species was detected at the outer Río de la Plata (F. Scarabino, personal communication).

We strongly stress the need for detailed studies of these groups, in order to increase the existing knowledge of the biodiversity on the Uruguayan coast. 
Acknowledgments - The field work was supported by The Maurice Laing Foundation Rufford Small Grant for Nature conservation. A.C. acknowledges financial support from CSIC. A.I.B. We would like to thank the Cleveland Metroparks Zoo for funding received. We would also like to thank F. Scarabino and Marcos Lhano for the valuable comments made on an earlier version of the manuscript.

\section{References}

BAIN, BA., 1991. Some observations on biology and feeding behavior in two southern California Pycnogonids, Bijdr. Dierk., vol. 61 , no. 1, p. 63-64.

CALIARI D., DEFEO O., CERVETO, G., GÓMEZ, M., JIMÉNEZ L., SCARABINO, F., BRAZEIRO, A. and NORBIS, W., 2003. Marine life of Uruguay: critical update and priorities for future research. Gayana, vol. 67, no. 2, p. 341-370.

GENZANO, GN., 2002. Associations between Pycnogonids and hydroids from the Buenos Aires littoral zone, with observations on the semi-parasitic life cycle of Tanystylum orbiculare (Ammotheidae). Sci. Mar., vol. 66, no. 1, p. 83-92.

JUANICÓ, M. and RODRÍGUEZ-MOYANO, M., 1976. Composición faunística de la comunidad de Mytilus edulis platensis d'orbigny, 1846 ubicada a unas 55 millas al SE de La Paloma. Com. Soc. Mal. Uruguay, vol. 4, no. 29, p. 113-116.

LARAMENDY, ML., 1974. Anotaciones sobre Colossendeis geofroyi (Mañe-Garzón, 1944). Neotrópica, vol. 20, no. 63, p. $149-152$

MARCUS, E., 1940. Os pantopoda brasileiros e os demais sul-americanos. Bol. Fault. Fil., Cien., Letr., vol. 19, no. 4, p. 3-144.

STAPLES, DA., 2002.Pycnogonum (Pycnogonida:Pycnogonidae) from Australia with descriptions of two new species. Mem. Mus. Victoria., vol. 59, no. 2, p. 541-553

STAPLES, DA. and WATSON, JE., 1987. Associations between Pycnogonids and hydroids, In: J. Bouillon, F. Boero, F. Cicogna and P. F. S. Cornelius (eds.), Modern Trends in the Systematics, Ecology, and Evolution of Hydroids and Hydromedusae, Oxford University Press, p. 215-226.

STOCK, JH., 1966. Résultats scientifiques des campagnes de la "Calypso". Fascicule VII. Campagne de la Calypso au large des cotes atlantiques de l'Amerique du Sud (1961-1962). I. 4 Pycnogonida. Ann. Inst. Oceanogr. Monaco, vol. 44, p. $385-406$. 
